\title{
Effects of Oxygen Deprivation and Pythium Root Rot on Sugarcane Red Rot
}

\author{
Zhi Yin and J. W. Hoy, Department of Plant Pathology and Crop Physiology, Louisiana Agricultural Experiment \\ Station, Louisiana State University Agricultural Center, Baton Rouge 70803
}

\begin{abstract}
Yin, Z., and Hoy, J. W. 1998. Effects of oxygen deprivation and Pythium root rot on sugarcane red rot. Plant Dis. 82:1237-1241.

The effects of oxygen deprivation or poor drainage and Pythium root rot on development of red rot, caused by Colletotrichum falcatum, and spring shoot population of sugarcane were evaluated under controlled and field conditions. Detached stalks of five cultivars were exposed to low atmospheric oxygen ( 0.5 to $2.7 \%$ ), created by enclosing stalks in sealed chambers through which humidified nitrogen gas was passed for 0,1 , or 2 weeks. Stalks were then inoculated with C. falcatum and maintained for 6 weeks with humidified air flow. Red rot severity, assessed as four disease traits, was not increased by previous oxygen deprivation. In field experiments, inoculation of stalks of three cultivars with $C$. falcatum before planting resulted in a reduction in shoot populations the following spring. Poor drainage resulted in an additional reduction in shoot populations developing from inoculated stalks. Soil atmospheric oxygen was reduced in the root zone below planted stalks under poor drainage conditions. However, only minor reductions in oxygen were detected in the zone of elevated rows in which planted stalks were located. The detrimental effect of poor drainage on shoot populations from inoculated stalks was alleviated by metalaxyl application. Pythium root rot, caused by Pythium arrhenomanes, reduced the initial root system and growth of shoots in greenhouse experiments. The combination of $P$. arrhenomanes and C. falcatum inoculation increased dead bud percentage in one of two cultivars and red rot severity for both. The results suggest that spring shoot populations developing from red rot-affected stalks exposed to poor drainage can be reduced by the combined effects of red rot and Pythium root rot.
\end{abstract}

In Louisiana, sugarcane, interspecific hybrids of the genus Saccharum, is vegetatively propagated by planting whole stalks during August and September. After planting, bud germination and the development of roots from primordia at the nodes begin. Young shoots depend on nodal roots for water and mineral salts for growth until shoot roots develop (11). Shoot and root growth are dependent on nutrition obtained from the internode tissues of planted stalks. Additional factors affecting the initial growth of young roots and shoots include injuries to the stalk, pathogens, soil temperature and moisture, and the position of buds in the soil $(1,2,11)$. During winter, the planted stalks and young plants are exposed to unfavorable temperatures and possibly waterlogging or drought. Red rot, caused by Colletotrichum falcatum Went $(1,2,5,14)$, and root rot, caused by Pythium arrhenomanes Drechs., $(7,9,10,12)$ are diseases of potential importance.

Corresponding author: J. W. Hoy

E-mail: jhoy@agctr.lsu.edu

Approved for publication by the Director of the Louisiana Agricultural Experiment Station as manuscript number: 98-38-0058.

Accepted for publication 30 July 1998.

Publication no. D-1998-0825-01R

(C) 1998 The American Phytopathological Society
Red rot can cause severe losses in stalk population, stalk juice quality, and yield of sucrose $(1,5,14,17)$. The pathogen infects stalks through wounds and nodes $(4,13)$. In Louisiana, red rot affects primarily planted stalks and adversely affects yield by reducing shoot populations the spring following planting (1). Pythium root rot can cause significant reductions in root and shoot weight and shoot number $(7,9,10,12)$. Rotting of the initial stalk roots can inhibit bud germination and initial shoot growth (12).

Environmental conditions affect the development of both diseases. Experimental evidence confirmed that red rot severity is increased by the occurrence of drought conditions at the beginning of the bud germination process (20). Observational evidence suggests that red rot is favored by excessive soil moisture and low temperature. These factors can adversely affect sugarcane growth but have much less effect on the pathogen (3,14-16). P. arrhenomanes is capable of growing and reproducing under a broad range of temperatures, and zoospore production and dispersal and severe disease development are favored by wet soil conditions $(8,18)$. However, the interaction between red rot, Pythium root rot, and environmental stress due to poor drainage or waterlogging is poorly understood. Therefore, the objective of this study was to determine the effects of oxygen deprivation or poor drainage and Pythium root rot on red rot development and spring shoot population of sugarcane. A portion of these results was reported previously (21).

\section{MATERIALS AND METHODS}

Oxygen deprivation experiments under controlled conditions. Five commercial sugarcane cultivars, CP 65-357, CP 70-321, CP 72-370, LCP 82-89, and LCP 85-384, were included. Three treatments were applied prior to inoculation with $C$. falcatum: 1 or 2 weeks of oxygen deprivation and no deprivation. After surface-disinfection by dipping stalks into an approximately $0.26 \% \mathrm{NaOCl}$ solution for 30 min, four detached and topped stalks of each cultivar with nine nodes and no stalk borer or mechanical injury were put into a treatment chamber made of 30-cm-diameter polyvinylchloride (PVC) pipe $1.83 \mathrm{~m}$ in length. Chambers were then sealed with opaque Plexiglas plates. Humidified nitrogen gas was passed through chambers to create an oxygen deficit. Humidified air flow was provided in the control chamber. The oxygen content in the treatment chamber was determined twice daily using a portable oxygen probe (DO-166, Lazar Research Laboratories, Los Angeles, CA) and $\mathrm{mV}$ meter (Model 6009, JANCO Electronics LTD, San Diego, CA). A 10 $\mathrm{cm}^{3}$ ambient atmosphere air sample was collected with a syringe and passed through the probe to get a current reading value; then the process was repeated with a $10 \mathrm{~cm}^{3}$ air sample withdrawn from the treatment chambers. The oxygen content in the chambers was then calculated as: $21 \%$ $\times$ gas chamber $\mathrm{mV}$ value/ambient atmosphere $\mathrm{mV}$ value. After 2 weeks, the chambers were opened, and stalks were inoculated with $C$. falcatum by introducing 100 $\mu \mathrm{l}$ of a conidial suspension of $3.8 \times 10^{6}$ spores per $\mathrm{ml}$ into a $3.2-\mathrm{mm}$-diameter hole drilled into but not through the first complete internode from each end of the stalk. Inoculated stalks were then incubated for another 6 weeks in the chambers with humidified air flow.

Red rot development was determined at the end of the experiment. Disease severity was assessed as: (i) total number of nodes beyond which internode rot symptoms were evident (nodes passed) toward the center from both inoculation points, (ii) the number of nodes rotted in the assessed area, and (iii) internode rot severity (IRS) in the inoculated internodes and internodes toward the center from both inoculation points. Internode rot severity was evaluated by visually rating the portion of tissue 
exhibiting red discoloration in each inter1 to 6 scale: $1=10 \%$ or less discolored tissue, $2=11$ to $25 \%, 3=26$ to $50 \%, 4=$ 51 to $75 \%, 5=76$ to $90 \%$, and $6=$ greater than $90 \%$ discolored tissue. Internode rot severity was then determined as an average of the eight internodes assessed. An aggregate disease trait, rot severity index (RI), combining the traits describing the extent of internode rotting and disease spread was calculated as RI $=$ IRS $\times$ nodes passed. The experiment was conducted twice.

Field experiments. Two experiments were conducted at the Sugar Research Station of the Louisiana Agricultural Experiment Station at St. Gabriel, using three cultivars, CP 65-357, CP 72-370, and LCP 82-89. Detached and topped mature stalks with nine nodes and no stalk borer or mechanical injury were dipped into an approximately $0.26 \% \mathrm{NaOCl}$ solution for 30 each cultivar. One group was inoculated as described previously once in the center internode, and the other group was drilled but not inoculated. Half of the inoculated and noninoculated stalks were planted under poor field drainage conditions, and the other half of each were planted under normal drainage conditions. Poor drainage was created by placing earth dams in the drainage furrows between plots. A splitplot design with three replicates was used, where the main plots were poor and normal drainage. Inoculated and noninoculated stalks of each cultivar were randomly planted in main plots in single rows $7.66 \mathrm{~m}$ in length. Six stalks per plot were planted during fall 1993 and 1994. Development of red rot symptoms was checked monthly by sampling stalks from each treatment.

To test whether Pythium root rot affects the relationship between red rot and spring shoot population, application of the oomycete-selective fungicide metalaxyl was added as a treatment. The three cultivars and experimental design were the same as described above. Metalaxyl was applied at a rate of $216 \mu \mathrm{l}$ a.i. (Ridomil 2E, Novartis, Greensboro, NC) in 4 liters of water to the node. Ratings were made on the following min, and then divided into two groups for

soil surface of each plot in both main plots at the beginning of the experiment, then 1 and 2 months after planting. The planting furrow was still open at the time of first application. The experiment was conducted twice.

Gas samplers, from which soil atmospheric gas can be collected, were constructed by attaching a sintered bronze cup to a $15-\mathrm{cm}$ length of $2.45-\mathrm{cm}$-diameter PVC pipe with a sampling tap at the top (6). Samplers were buried in elevated planting rows at two depths from the row top surface. At each site, one was placed at the planting depth of the stalks (approximately 10 to $13 \mathrm{~cm}$ ), and the other was approximately $7 \mathrm{~cm}$ below. Eight samplers in total were placed in each main plot (drainage type). Soil atmospheric oxygen was monitored weekly using the portable oxygen probe and $\mathrm{mV}$ meter. A 10$\mathrm{cm}^{3}$ ambient atmosphere air sample was collected with a syringe and passed through the probe to get a current reading value, then the process was repeated with a $10-\mathrm{cm}^{3}$ air sample withdrawn from the samplers. The soil atmosphere oxygen was then calculated as described previously. Rainfall data were provided from a rain gauge monitored daily at the Sugar Research Station. The number of shoots in each plot was counted in April during the spring following planting.

Red rot and Pythium root rot greenhouse experiments. Two experiments were conducted in the greenhouse with two cultivars, CP 65-357 and LCP 82-89. Mature stalks without stalk borer or mechanical injury were hand-cut. After dipping into an approximately $0.26 \% \mathrm{NaOCl}$ solution for $30 \mathrm{~min}$, stalks were cut into two pieces with four or five nodes each. Four treatments consisted of: (i) noninoculated stalk sections planted into a steam-treated (overnight) silt loam soil:sand mixture $(1: 1, \mathrm{vol} / \mathrm{vol})$, (ii) $C$. falcatum-inoculated stalk sections planted into steam-treated soil:sand mixture, (iii) noninoculated stalk sections planted into steam-treated soil:sand mixture containing $P$. arrhenomanes inoculum, and (iv) $C$.

Table 1. Red rot development in stalks of five cultivars combined with and without oxygen deprivation prior to inoculation

\begin{tabular}{lcccc}
\hline & \multicolumn{4}{c}{ Disease trait $^{\mathbf{z}}$} \\
\cline { 2 - 5 } Treatment $^{\mathbf{y}}$ & Nodes passed & Nodes rotted & $\begin{array}{c}\text { Internode rot }_{\text {severity }(\%)} \\
\text { No OD } \\
\text { Not index }\end{array}$ \\
1 week OD & $3.5 \mathrm{a}$ & $3.0 \mathrm{a}$ & $52 \mathrm{a}$ & $1.96 \mathrm{a}$ \\
2 week OD & $3.6 \mathrm{a}$ & $3.2 \mathrm{a}$ & $49 \mathrm{a}$ & $1.91 \mathrm{a}$ \\
\hline
\end{tabular}

${ }^{\mathrm{y}}$ No $\mathrm{OD}=$ no oxygen deprivation, 1 week OD = stalks exposed to oxygen deprivation for 1 week before inoculation, and 2 week $\mathrm{OD}=$ stalks exposed to oxygen deprivation for 2 weeks before inoculation. Values are means from two experiments combined. Means within a column followed by the same letter were not significantly different $(P=0.05)$ as determined by Fisher's protected least significant difference test.

${ }^{\mathrm{z}}$ Nodes passed $=$ total number of nodes beyond which internal internode rot symptoms extended from the inoculation points in the second internodes from each stalk end, nodes rotted $=$ total number of nodes with rot symptoms, internode rot severity = mean percent discoloration of eight total internodes, and rot index $=$ nodes passed $\times$ internode rot severity. falcatum-inoculated stalk sections planted into steam-treated soil:sand mixture containing $P$. arrhenomanes.

Inoculation with $C$. falcatum was as described previously. Twenty-four stalk sections containing three to four internodes from 12 stalks were inoculated for each cultivar in a center internode. Another set of sections from 12 stalks was drilled but not inoculated with $C$. falcatum. The $P y$ thium inoculum was prepared by a modification of a method described previously (19) in which $450 \mathrm{~cm}^{3}$ of vermiculite and $20 \mathrm{ml}$ of whole oat seeds with $300 \mathrm{ml}$ of $\mathrm{V} 8$ vegetable juice preparation $(200 \mathrm{ml}$ of $\mathrm{V} 8$ juice, $800 \mathrm{ml}$ of water, and $2 \mathrm{~g}$ of $\left.\mathrm{CaCO}_{3}\right)$ in a 1-liter Mason jar was autoclaved twice in $48 \mathrm{~h}$. Each jar was inoculated with agar disks from a $P$. arrhenomanes culture. The substrate was colonized for 2 to 3 weeks at room temperature. Inoculum was placed in cheesecloth and thoroughly rinsed with water, and excess water was squeezed out. $P$. arrhenomanes inoculum $(180 \mathrm{~g})$ was then mixed into individual metal trays $(50 \times 35 \times 9 \mathrm{~cm})$ of soil:sand mixture.

Four stalk sections (two from each of two stalks) were planted per tray, so that three trays contained a total of six stalks of each cultivar per treatment. Trays were arranged on a greenhouse bench in a completely randomized design. Plants were grown for 4 weeks in the greenhouse with air temperatures ranging between 21 and $28^{\circ} \mathrm{C}$.

Plant growth and red rot and root rot severity were evaluated after 4 weeks. All stalk sections with attached shoots and roots were gently washed free of soil. Measurements taken for each stalk section included number of live buds or shoots, number of dead buds, total shoot dry weight, and total root dry weight. The percentage of dead buds was calculated from the live and dead bud data. In addition, the root system of each stalk section was evaluated by subjective visual rating for root discoloration caused by Pythium root rot. Visual ratings were made on a scale of 1 to 6 in which: $1=$ less than $10 \%$ of the root system discolored, $2=11$ to $25 \%, 3=$ 26 to $50 \%, 4=51$ to $75 \%, 5=76$ to $90 \%$, and $6=91$ to $100 \%$ root discoloration. Rotting of internal internode tissue caused by $C$. falcatum was assessed by splitting the stalk section longitudinally. Internode rot severity was evaluated by visually rating the portion of tissue exhibiting red discoloration in each internode as described previously.

Statistical analyses. Data were analyzed by using the general linear model procedures of the Statistical Analysis System, Version 6.12 (SAS Institute, Cary, NC). Data from repeated experiments were combined and subjected to analysis of variance with experiments as blocks. Results of analyses for which the block (experiment) effect was not significant are 
presented for combined experiments. When no cultivar by treatment interaction effect was detected, cultivar data were combined to analyze treatment effects. Ratings data for internode rot severity and root discoloration were converted to the percentage midpoint for the appropriate interval and then transformed to arcsine square root values before statistical analysis. Dead bud percentages also were transformed before analysis. Dry weights for total shoots and roots developing from nodes were converted into individual shoot dry weight and root dry weight per node based on the number of nodes of each stalk section. Differences among treatment means were determined by using Fisher's protected least significant difference test at the $5 \%$ level of probability. Data from oxygen samplers were transformed, and the results from normal and poor drainage plots were compared by a paired $t$ test for each sampling depth during 1993 to 1994 and 1994 to 1995 .

\section{RESULTS}

Effect of oxygen deprivation on red rot development under controlled conditions. Oxygen deprivation prior to inoculation for 1 or 2 weeks did not increase red rot severity assessed as number of nodes beyond which symptoms had progressed, number of nodes rotted, internode rot severity, or a rot index. The results were similar for all five cultivars, so the data were combined (Table 1).

Field experiments. Decreases in soil atmospheric oxygen content detected with

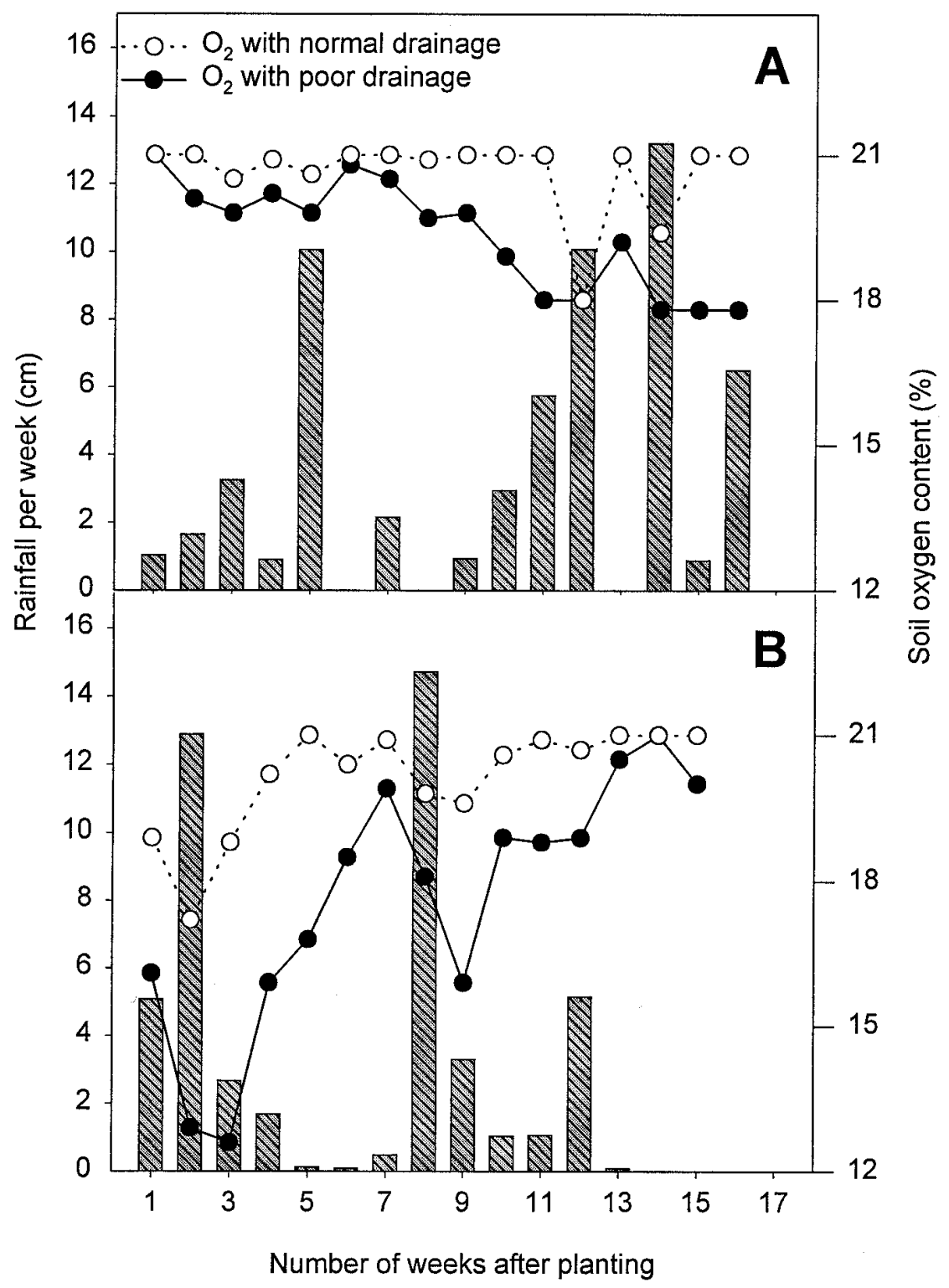

Fig 1. Effect of rainfall on soil oxygen content at a 17 - to $20-\mathrm{cm}$ depth in the sugarcane planting row. Oxygen levels were determined once per week for plots with normal and poor drainage, and rainfall amounts (bars) represent weekly totals. (A) Results for 16 weeks following planting during fall and winter 1993 to 1994. (B) Results for 16 weeks following planting during fall and winter 1994 to 1995. samplers placed at the 17 - to 20 -cm depth, below stalks within the planting row, were associated with the occurrence of rainfall during two fall and winter periods (Fig. 1A and $\mathrm{B})$. Rainfall patterns and decreases in soil oxygen varied during the two periods of the study. Soil oxygen was lower in poorly drained plots during 1993 to 1994 and 1994 to 1995 . Only minor reductions in oxygen content were detected with samplers placed at the planting depth of stalks $(10$ to $13 \mathrm{~cm}$ ) (data not shown). However, oxygen content was lower in the poorly drained plots during 1994 to 1995. The means for normal and poor drainage plots during this period were $20.6 \pm 0.2 \%$ (standard error) and $18.5 \pm 0.5 \%$, respectively.

The results were similar in both experiments for each of three cultivars, so the data were combined. The highest spring shoot populations were obtained from planted stalks without inoculation with $C$. falcatum and normal or poor field drainage conditions, and the lowest shoot population occurred in the inoculation and poor drainage treatment (Table 2). Poor drainage

Table 2. Effects of stalk inoculation with $\mathrm{Col}$ letotrichum falcatum and poor drainage on spring shoot populations of three cultivars combined

\begin{tabular}{lc}
\hline Treatment $^{\mathbf{y}}$ & $\begin{array}{c}\text { Spring shoot } \\
\text { population per } \text { plot }^{\mathbf{z}}\end{array}$ \\
\hline NI/ND & $42 \mathrm{a}$ \\
NI/PD & $35 \mathrm{ab}$ \\
I/ND & $32 \mathrm{~b}$ \\
I/PD & $25 \mathrm{c}$ \\
\hline
\end{tabular}

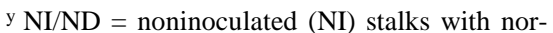
mal drainage (ND), NI/PD = noninoculated stalks with poor drainage $(\mathrm{PD}), \mathrm{I} / \mathrm{ND}=$ inoculated with normal drainage, and $\mathrm{I} / \mathrm{PD}=$ inoculated with poor drainage.

${ }^{\mathrm{z}}$ Values are means from two experiments. Means within a column followed by the same letter were not significantly different $(P=$ 0.05 ) as determined by Fisher's protected least significant difference test.

Table 3. Effects of stalk inoculation with $\mathrm{Col}$ letotrichum falcatum and poor drainage on spring shoot populations of three cultivars combined when the fungicide metalaxyl was applied to all treatments

\begin{tabular}{lc}
\hline Treatment $^{\mathbf{y}}$ & $\begin{array}{c}\text { Spring shoot } \\
\text { population per } \text { plot }^{\mathbf{z}}\end{array}$ \\
\hline NI/ND & $40 \mathrm{a}$ \\
NI/PD & $34 \mathrm{ab}$ \\
I/ND & $31 \mathrm{~b}$ \\
I/PD & $31 \mathrm{~b}$ \\
\hline
\end{tabular}

y NI/ND = noninoculated (NI) stalks with normal drainage $(\mathrm{ND}), \mathrm{NI} / \mathrm{PD}=$ noninoculated stalk with poor drainage (PD), I/ND = inoculated with normal drainage, and $\mathrm{I} / \mathrm{PD}=\mathrm{in}-$ oculated with poor drainage.

${ }^{z}$ Values are means from two experiments. Means within a column followed by the same letter were not significantly different $(P=$ 0.05 ) as determined by Fisher's protected least significant difference test. 
without inoculation did not result in a spring shoot reduction, whereas inoculation with normal drainage did.

The experimental results were different when metalaxyl was applied to all treatments (Table 3). The shoot population that developed under normal drainage conditions was still lower when stalks were inoculated with $C$. falcatum. However, the population was not reduced further by the imposition of poor drainage on $C$. falcatum-inoculated stalks.

Effects of $\boldsymbol{C}$. falcatum and $P$. arrhenomanes in greenhouse experiments. $C$. falcatum did not affect the development of roots from stalk nodes of the two cultivars, whereas $P$. arrhenomanes caused root rot assessed as discoloration and reduced weight (Table 4). The root system weight reduction was less in the combined pathogen treatment than for the $P$. arrhenomanes-only treatment for CP 65-357.

Stalk inoculation with $C$. falcatum resulted in an increase in the weight of developing shoots, while $P$. arrhenomanes decreased shoot weight for LCP 82-89 (Table 5). The pathogens, when combined, did not cause a further decrease in shoot weight of LCP 82-89. However, together, they reduced the weight of $\mathrm{CP}$ 65-357 shoots. C. falcatum and $P$. arrhenomanes individually caused an increase in the frequency of dead buds for CP 65-357, and the combination of the two pathogens caused a higher dead bud percentage (Table 5). In contrast, neither pathogen alone nor both combined affected the frequency of dead buds for LCP 82-89 (Table 5).

Rotting of the stalk internode tissue was caused by $C$. falcatum, but not $P$. arrhenomanes (Table 6). However, stalk rot was more severe when $P$. arrhenomanes was combined with $C$. falcatum for both cultivars (Table 6).

\section{DISCUSSION}

An extensive body of observational evidence suggests excess soil moisture contributes to severe red rot of standing and planted cane $(1,2,5,14)$. However, experimental evidence concerning how excess soil moisture increases red rot severity is lacking. In the controlledconditions experiments, the oxygen deprivation treatments were intended to mimic the effect of waterlogging. The results from these experiments suggest that oxygen deprivation does not predispose planted sugarcane to increased red rot severity. In the field experiments, poor drainage conditions resulted in greater spring shoot population reductions for stalks inoculated with $C$. falcatum, but only minor reductions in soil oxygen content were detected in the zone of the elevated rows in which stalks were located. The effects of temporary periods of reduced soil atmospheric oxygen on sugarcane growth are unknown. In this study, spring shoot populations were not significantly reduced when noninoculated stalks were exposed to poor drainage.

Table 4. Effects of Colletotrichum falcatum and Pythium arrhenomanes on dry weight and discoloration of roots developing from stalk nodes for two cultivars in two greenhouse experiments combined

\begin{tabular}{|c|c|c|c|c|}
\hline \multirow[b]{2}{*}{ Treatment $^{\mathbf{y}}$} & \multicolumn{2}{|c|}{ Root weight per node $(\mathrm{g})^{\mathrm{z}}$} & \multicolumn{2}{|c|}{ Root system discoloration $(\%)^{z}$} \\
\hline & CP 65-357 & LCP 82-89 & CP 65-357 & LCP 82-89 \\
\hline Control & $0.61 \mathrm{a}$ & $0.62 \mathrm{a}$ & $5.0 \mathrm{~b}$ & $5.0 \mathrm{~b}$ \\
\hline $\mathrm{Cf}$ & $0.63 \mathrm{a}$ & $0.63 \mathrm{a}$ & $5.0 \mathrm{~b}$ & $5.0 \mathrm{~b}$ \\
\hline $\mathrm{Pa}$ & $0.28 \mathrm{c}$ & $0.22 b$ & $63.0 \mathrm{a}$ & $52.0 \mathrm{a}$ \\
\hline Cf\&Pa & $0.49 \mathrm{~b}$ & $0.31 \mathrm{~b}$ & $62.0 \mathrm{a}$ & $51.0 \mathrm{a}$ \\
\hline
\end{tabular}

y Control $=$ noninoculated stalks planted in steamed soil, $\mathrm{Cf}=$ stalks planted in steamed soil after inoculation with $C$. falcatum, $\mathrm{Pa}=$ stalks planted in soil with $P$. arrhenomanes inoculum and without inoculation with $C$. falcatum, and $\mathrm{Cf} \& \mathrm{~Pa}=$ stalks planted in soil with $P$. arrhenomanes inoculum after inoculation with $C$. falcatum.

${ }^{\mathrm{z}}$ Means in a column followed by the same letter were not different $(P=0.05)$, as determined by Fisher's protected least significant difference test.

Table 5. Effects of Colletotrichum falcatum and Pythium arrhenomanes on individual shoot dry weight and the percentage of dead buds for two cultivars in two greenhouse experiments combined

\begin{tabular}{|c|c|c|c|c|}
\hline \multirow[b]{2}{*}{ Treatment $\mathbf{y}^{\mathrm{y}}$} & \multicolumn{2}{|c|}{ Individual shoot weight $(\mathrm{g})^{\mathrm{z}}$} & \multicolumn{2}{|c|}{ Percent dead buds ${ }^{\mathrm{z}}$} \\
\hline & CP 65-357 & LCP 82-89 & CP 65-357 & LCP 82-89 \\
\hline Control & $0.90 \mathrm{ab}$ & $0.84 \mathrm{~b}$ & $8.3 \mathrm{c}$ & $13.2 \mathrm{a}$ \\
\hline $\mathrm{Cf}$ & $1.13 \mathrm{a}$ & $1.10 \mathrm{a}$ & $26.0 \mathrm{~b}$ & $13.5 \mathrm{a}$ \\
\hline $\mathrm{Pa}$ & $0.75 \mathrm{bc}$ & $0.55 \mathrm{c}$ & $29.5 \mathrm{~b}$ & $19.8 \mathrm{a}$ \\
\hline $\mathrm{Cf} \& \mathrm{~Pa}$ & $0.64 \mathrm{c}$ & $0.52 \mathrm{c}$ & $45.5 \mathrm{a}$ & $14.2 \mathrm{a}$ \\
\hline
\end{tabular}

y Control = noninoculated stalks planted in steamed soil, $\mathrm{Cf}=$ stalks planted in steamed soil after inoculation with $C$. falcatum, $\mathrm{Pa}=$ stalks planted in soil with $P$. arrhenomanes inoculum and without inoculation with $C$. falcatum, and $\mathrm{Cf} \& \mathrm{~Pa}=$ stalks planted in soil with $P$. arrhenomanes inoculum after inoculation with $C$. falcatum.

${ }^{\mathrm{z}}$ Means in a column followed by the same letter were not different $(P=0.05)$, as determined by Fisher's protected least significant difference test.

Previous research documented the importance of Pythium root rot in sugarcane $(7,9,10,12)$. In addition, an association between increased Pythium root rot severity and excess soil moisture was demonstrated experimentally $(8,18)$. These findings suggest the effect of soil moisture on red rot could be due to an indirect effect on root rot severity. The effect of Pythium root rot on the severity of red rot has not been investigated previously. However, it was shown that bud germination and the growth of shoots are retarded when roots developing from nodes of planted stalks are destroyed by root rot (12).

The greenhouse experiment results confirmed that Pythium root rot reduces the root system developing from stalk nodes and growth of shoots. In addition, the results showed that the combination of both pathogens can result in an increase in red rot stalk symptom severity. The field experiment results also suggest the involvement of both red rot and root rot in shoot population reductions. Decreases in shoot populations resulting from $C$. falcatum inoculation with poor drainage were additive. However, when metalaxyl was applied, this additive decrease was alleviated. Root infection by Pythium and root rot severity were not determined in the field experiments. However, the control of Pythium root rot in sugarcane with metalaxyl has been shown previously (10).

Red rot symptom severity varied among cultivars in the controlled conditions, field, and greenhouse experiments. However, the treatment effects were similar across cultivars, except in the greenhouse experiments. CP 65-357 exhibited more severe disease development than LCP 82-89 in all experiments; and in the greenhouse experiments, the combination of red rot and root rot resulted in an increase in the percentage of dead buds in CP 65-357. The

Table 6. Effects of Colletotrichum falcatum and Pythium arrhenomanes on internode rot severity in stalks of two cultivars in two greenhouse experiments combined

\begin{tabular}{lcc}
\hline & \multicolumn{2}{c}{ Internode rot severity $(\%)^{\mathbf{z}}$} \\
\cline { 2 - 3 } Treatment $^{\mathbf{y}}$ & $\mathbf{C P 6 5 - 3 5 7}$ & $\mathbf{L C P ~ 8 2 - 8 9}$ \\
\hline Control & $3.9 \mathrm{c}$ & $2.0 \mathrm{c}$ \\
$\mathrm{Cf}$ & $28.5 \mathrm{~b}$ & $14.3 \mathrm{~b}$ \\
$\mathrm{~Pa}$ & $4.5 \mathrm{c}$ & $7.1 \mathrm{c}$ \\
$\mathrm{Cf} \& \mathrm{~Pa}$ & $38.8 \mathrm{a}$ & $26.9 \mathrm{a}$ \\
\hline
\end{tabular}

y Control $=$ noninoculated stalks planted in steamed soil, $\mathrm{Cf}=$ stalks planted in steamed soil after inoculation with $C$. falcatum, $\mathrm{Pa}=$ stalks planted in soil with $P$. arrhenomanes inoculum and without inoculation with $C$. falcatum, and $\mathrm{Cf} \& \mathrm{~Pa}=$ stalks planted in soil with $P$. arrhenomanes inoculum after inoculation with $C$. falcatum.

${ }^{\mathrm{z}}$ Internode rot severity is the mean percent discoloration for internodes in a three or four internode stalk section. Means in a column followed by the same letter were not different $(P=0.05)$ as determined by Fisher's protected least significant difference test. 
dead bud percentage for LCP 82-89 was unaffected by pathogen treatments, and shoot weight was actually greater for stalks inoculated with $C$. falcatum. The explanation for this increase in shoot growth rate is unknown.

In summary, oxygen deprivation did not predispose stalks to increased stalk red rot severity. Furthermore, the sugarcane cultivation practice of planting stalks in elevated rows minimizes the occurrence of waterlogging. The metalaxyl treatment results suggest the factor responsible for the additive effect of red rot and poor drainage was an increase in Pythium root rot, and it was demonstrated in the greenhouse that Pythium root rot can increase the severity of red rot. When considered altogether, the experimental evidence suggests that shoot populations developing from red rot-affected stalks under poor drainage conditions can be reduced by the combined effects of red rot and Pythium root rot.

\section{LITERATURE CITED}

1. Abbott, E. V. 1938. Red rot of sugarcane. U.S. Dep. Agric. Tech. Bull. 641.

2. Agnihotri, V. P. 1990. Diseases of Sugarcane and Sugarbeet. Oxford \& IBH Publishing Co. Pvt. Ltd., New Delhi.

3. Ahmed, H. U., and Divinagracia, G. G. 1974. Growth and sporulation of Colletotrichum falcatum at different temperature, $\mathrm{pH}$, and light conditions. Philipp. Agric. 57:379-382.

4. Chona, B. L. 1950. Studies on the diseases of sugarcane in India. III. Sources and modes of red rot infection. Ind. J. Agric. Sci. 20:363385.

5. Chona, B. L. 1980. Red rot of sugarcane and sugar industry - a review. Ind. Phytopathol. 33:191-206.

6. Dowdell, R. J., Smith, R. A., Crees, R., and Restall, S. W. F. 1972. Field studies of ethylene in the soil atmosphere-equipment and preliminary results. Soil Biol. Biochem. 4:1472-1480.

7. Edgerton, C. W., Tims, E. C., and Mills, P. J. 1929. Relation of species of Pythium to the root-rot disease of sugarcane. Phytopathology 19:549-564.

8. Flor, H. H. 1930. Relation of environmental factors to growth and pathogenicity of $P y$ thium isolated from roots of sugar cane. Phytopathology 20:319-328.

9. Hoy, J. W., and Schneider, R. W. 1988. Role of Pythium in sugarcane stubble decline: Pathogenicity and virulence of Pythium species. Phytopathology 78:1688-1692.

10. Hoy, J. W., and Schneider, R. W. 1988. Role of Pythium in sugarcane stubble decline: Effects on plant growth in field soil. Phytopathology 78:1692-1696.

11. Julien, M. H. R., Irvine, J. E., and Benda, G. T. A. 1988. Sugarcane anatomy, morphology and physiology. Pages 1-19 in: Diseases of Sugarcane - Major Diseases. C. Ricaud, B. T. Egan, A. G. Gillaspie, Jr., and C. G. Hughes, eds. Elsevier, New York.

12. Rands, R. D., and Dopp, E. 1938. Pythium root rot of sugarcane. U.S. Dep. Agric. Tech. Bull. No. 666.

13. Singh, G. R. 1968. Red rot infection and its development in young sugarcane plants. Proc. Int. Soc. Sugar Cane Technol. 13:1243-1250.

14. Singh, K., and Singh, R. H. 1988. Red rot Pages 169-188 in: Diseases of Sugarcane Major Diseases. C. Ricaud, B. T. Egan, A. G. Gillaspie, Jr., and C. G. Hughes, eds. Elsevier, New York.

15. Singh, N., and Lal, R. J. 1987. Viability of red rot pathogen under waterlogged conditions. Plant Dis. Rep. 2:104-105.

16. Singh, N., Lal, S., and Singh, R. P. 1985. Behavior of Colletotrichum falcatum under stress condition. Ind. Phytopathol. 38:544545.

17. Singh, O., and Waraitch, K. S. 1981. Effect of wilt and red rot induced disease stress on quality deterioration of sugarcane. Sugarcane Pathol. Newsl. 27:25-29.

18. Van der Zwet, T. 1957. The effect of flooding upon the severity of Pythium root rot. M.S thesis. Louisiana State University, Baton Rouge.

19. Wilcox, W. F., and Mircetich, S. M. 1985. Pathogenicity and relative virulence of seven Phytophthora spp. on Mahaleb and Mazzard cherry. Phytopathology 75:221-226.

20. Yin, Z., and Hoy, J. W. 1997. Effect of stalk desiccation on sugarcane red rot. Plant Dis. 81:1247-1250.

21. Yin, Z., Hoy, J. W., and Milligan, S. B. 1994. Heritability of resistance to sugarcane red rot and the effect of environmental stress on disease severity. (Abstr.) Phytopathology 84:1148. 